\title{
Total versus partial chordal preservation in mitral valve replacement: Early results
}

\author{
Authors \\ Dr Sunil Dhar MC.h CTVS, Dr Sistla. V.P.L. Chandra Kumar MC.h CTVS, \\ Dr Madhur Kumar MC.h, Dr Anubhav Gupta-H.O.D.CTVS, Dr Ajit Kumar Padhy* \\ Department of Cardiothoracic and Vascular Surgery, VMMC and Safdarjung Hospital, Delhi, India \\ *Corresponding Author \\ Dr Ajit Kumar Padhy \\ Department of Cardiothoracic and Vascular Surgery, VMMC and Safdarjung Hospital, Delhi, India
}

\section{Introduction}

The annulo-papillary continuity in mitral valve withstands the hydrostatic force during systole as the chords relay the engendered forces between the leaflets and ventricular wall via contracted papillary muscles. It maintains the structural integrity of tensioned ventricular mass, disruption of which results in deterioration of left ventricular functions in patients undergoing mitral valve replacement.

It has been widely emphasised by authors that the post operative functional outcomes are better with chordal preservation techniques. It is seldom performed in institutions routinely during mitral valve surgery due to the technical complexities involving longer operating time, severe subvalvular calcifications, left ventricular outflow tract obstruction (LVOTO). ${ }^{1-5}$. Patients with septal hypertrophy undergoing anterior leaflet preservation may develop LVOTO as preserved tissue interferes with prosthetic valve functions ${ }^{6}$.

In the similar line, we have studied the varied early outcomes of chordal preservation strategy during mitral valve replacement.

\section{Methods}

This is a retrospective study of 168 patients who underwent mitral valve replacement (MVR) for both chronic rheumatic mitral stenotic and regurgitant lesions at our institution from January 2016 to January 2018.Dataobtained from patient files and outpatient follow-up were evaluated. The patients were divided into 3 groups: Group A $(n=37)$ where total excision of leaflets done with no chordal preservation. Group B $(n=87)$ where posterior leaflet along with its subvalvular structures preserved and Group C $(n=44)$ where total chordal preservation done with partial excision of anterior leaflet.

Excluded from the study were patients undergoing coronary bypass concurrent with MVR, reoperation for MVR, simultaneous aortic valve or aortic surgery, or surgical incision other than sternotomy. All patients having had given informed consent for operation and for use of their medical records for research purposes. All patients received a mechanical bileaflet valve. It was ensured that the preserved chordae tendinae were not interfering with the prosthesis function by 
checking disc movement. The technique for preservation of the chordo-papillary apparatus was decided after intraoperative visual inspection of the mitral valve.

\section{Techniques of Chordal Preservation}

Total Chordal Preservation: The anterior leaflet was mainly by the modified Miki'stechnique ${ }^{7}$ The anterior leaflet is partially excised, a flap is cut from the central portion of anterior leaflet anchored to the anterior mitral annulus with polyster sutures. Teflon pledgeted sutures separately used to anchor the prosthesis with remnant of anterior (mural) leaflet and posterior leaflet (Fig. A and B)

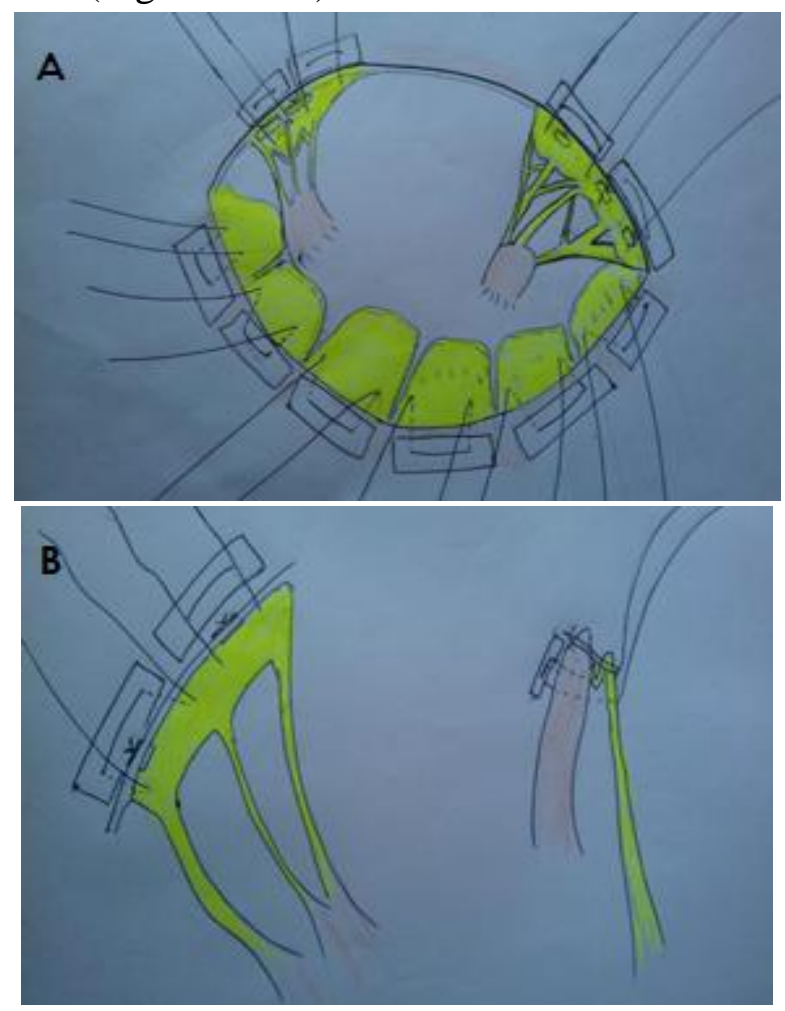

(Figure A,B: Mural leaflet is attached with anterior mitral annulus, close to the commisures with braided 2-0 polyester sutures followed by Teflon pledgeted sutures (Atrium to ventricle to leaflet to sewing ring) to minimize any tissue interference of prosthetic valve leaflets)

Partial Chordal Preservation: It involved excision of whole of the anterior leaflet and chordae tendinae with preservation of the posterior leaflet and associated subvalvular apparatus. The posterior leaflet was shaved off excess tissue or imbricated to the annulus using the same polyster sutures used for implantation of the prosthetic valve after incising the leaflet from edge to base at two or three points in between the scallops.

No Chordal Preservation/ Total excision: was done in severely calcified mitral valves with severe subvalvular calcification and fusion. It involved excision of whole of the mitral valve including the leaflets and subvalvular apparatus.

For follow up of these patients, Transthoracic echocardiography was done at the time of discharge and during subsequent follow ups. The functional class was also assessed at follow-up. All patients received oral anticoagulation to maintain an international normalized ratio (INR) between 2.5 and $3.5 .^{8}$

Transthoracic two-dimensional (2D), colour flow and Doppler echocardiography was performed using the PHILIPS machine with 2.5-3.7 MHz transducer. Prosthetic valve function was assessed on 2D and Doppler with multiple views. Echocardiographic data were measured according to the criteria of the American Society of Echocardiography. ${ }^{9}$ Echocardiography variables were noted and compared with preoperative echo reports.

\section{Statistical Analysis}

Statistical analysis was performed by the SPSS program for Windows, version 17.0 .Continuous variables are presented as mean $\pm \mathrm{SD}$, and categorical variables are presented as absolute numbers and percentage. Data were checked for normality before statistical analysis using Shaipro Wilk test. Normally distributed continuous variables were compared using ANOVA. If the F value was significant and variance was homogeneous, Tukey multiple comparison test was used to assess the differences between the individual groups; otherwise, Tamhane's T2 test was used. Categorical variables were analyzed using the chi square test. For all statistical tests, a $\mathrm{p}$ value less than 0.05 was taken to indicate a significant difference. 


\section{Results}

Demography of the patients has been mentioned in Table 1(a), 1(b) no statistically significant differences observed among the groups. Group
$\mathrm{A}=$ No chordal preservation/Total excision, Group $\mathrm{B}=$ Partial chordal preservation group, Group- $\mathrm{C}=$ Total chordal preservation group

Table 1(a)

Table 1(b)

\begin{tabular}{|l|c|c|c|c|}
\hline \multirow{2}{*}{} & \multicolumn{3}{|c|}{ Chordal Preservation } & \multirow{2}{*}{ p value } \\
\cline { 2 - 4 } & $\begin{array}{c}\text { No } \\
\text { (Group-A) }\end{array}$ & $\begin{array}{c}\text { Post } \\
\text { (Group-B) }\end{array}$ & $\begin{array}{c}\text { Total } \\
\text { (Group-C) }\end{array}$ & \\
\cline { 2 - 4 } & Mean \pm SD & Mean \pm SD & Mean \pm SD & \\
\hline Age (Yrs) & $36.97 \pm 14.28$ & $35.47 \pm 13.15$ & $33.27 \pm 10.37$ & 0.417 \\
\hline Weight $($ Kg) & $46.57 \pm 10.58$ & $48.69 \pm 13.46$ & $47.45 \pm 12.39$ & 0.667 \\
\hline Height $(\mathrm{cm})$ & $153.03 \pm 10.87$ & $153.61 \pm 10.04$ & $152.84 \pm 11.07$ & 0.911 \\
\hline
\end{tabular}

\begin{tabular}{|l|c|c|c|c|}
\hline \multirow{3}{*}{ Sex } & \multicolumn{3}{|c|}{ Chordal Preservation } & \multirow{2}{*}{ p value } \\
\cline { 2 - 4 } & $\begin{array}{c}\text { No } \\
\text { (Group-A) }\end{array}$ & $\begin{array}{c}\text { Post } \\
\text { (Group-B) }\end{array}$ & $\begin{array}{c}\text { Total } \\
\text { (Group-C) }\end{array}$ & \\
\cline { 2 - 4 } & Frequency (\%) & Frequency (\%) & Frequency (\%) & \\
\hline Female & $17(45.9 \%)$ & $48(55.2 \%)$ & $28(63.6 \%)$ & \multirow{2}{*}{0.280} \\
\hline Male & $20(54.1 \%)$ & $39(44.8 \%)$ & $16(36.4 \%)$ & \\
\hline Total & $37(100 \%)$ & $87(100 \%)$ & $44(100 \%)$ & \\
\hline
\end{tabular}

Patient admitted with severe MS also had MR++.

Those patients having severe sub valvular calcifications underwent MVR with no chordal preservation or posterior chordal preservation depending upon intraoperative findings.

Table 2

\begin{tabular}{|l|c|c|c|c|}
\hline \multirow{2}{*}{ Diagnosis } & \multicolumn{3}{|c|}{ Chordal Preservation } & \multirow{2}{*}{ p value } \\
\cline { 2 - 4 } & No & Post & Total & \\
\cline { 2 - 4 } & Frequency (\%) & Frequency (\%) & Frequency (\%) & \\
\hline Predominantly MS & $34(91.1 \%)$ & $66(75.9 \%)$ & $30(68.2 \%)$ & \multirow{2}{*}{0.035} \\
\hline Predominantly MR & $398.1 \% 0$ & $21(24.1 \%)$ & $14(31.8 \%)$ & \\
\hline Total & $37(100 \%)$ & $87(100 \%)$ & $44(100 \%)$ & \\
\hline
\end{tabular}

History of previous interventions not significantly related as shown in Table 3.

Table 3

\begin{tabular}{|l|c|c|c|c|}
\hline \multirow{2}{*}{$\begin{array}{l}\text { Previous } \\
\text { Intervention }\end{array}$} & \multicolumn{3}{|c|}{ Chordal Preservation } & \multirow{2}{*}{ p value } \\
\cline { 2 - 4 } & No & Post & Total & \\
\cline { 2 - 4 } & Frequency (\%) & Frequency (\%) & Frequency (\%) & \\
\hline None & $34(91.9 \%)$ & $77(88.5 \%)$ & $40(90.9 \%)$ & \multirow{2}{*}{0.339} \\
\hline CMV & $2(5.4 \%)$ & $8(9.2 \%)$ & $1(2.3 \%)$ & \\
\hline PTMC+BMV & $1(2.7 \%)$ & $0(0.0 \%)$ & $0(0.0 \%)$ & \\
\hline Total & $0(0.0 \%)$ & $2(2.3 \%)$ & $3(6.8 \%)$ & \\
\hline
\end{tabular}

BMV=Ballon Mitral Valvotomy, CMV= Closed Mitral Valvotomy, PTMC= Percutinous transvenous mitral commissurotomy

Table 4 (a)

Effect on LV dimensions: Table 4(a) and 4(b)

\begin{tabular}{|c|c|c|c|c|c|c|c|}
\hline \multirow[t]{3}{*}{ LVES(mm) } & \multicolumn{3}{|c|}{ Chordal Preservation } & \multirow[t]{3}{*}{$p$ value } & \multirow{3}{*}{$\begin{array}{c}\text { No } \\
\text { V/S } \\
\text { Posterior }\end{array}$} & \multirow{3}{*}{$\begin{array}{c}\text { No } \\
\text { V/S } \\
\text { Total }\end{array}$} & \multirow{3}{*}{$\begin{array}{c}\text { Posterior } \\
\text { V/S } \\
\text { Total }\end{array}$} \\
\hline & $\begin{array}{c}\text { No } \\
\text { (Group-A) }\end{array}$ & $\begin{array}{c}\text { Posterior } \\
\text { (Group-B) }\end{array}$ & $\begin{array}{c}\text { Total } \\
\text { (Group-C) }\end{array}$ & & & & \\
\hline & Mean \pm SD & Mean \pm SD & Mean \pm SD & & & & \\
\hline Preoperative & $36.97 \pm 8.97$ & $39.91 \pm 9.42$ & $37.52 \pm 9.38$ & 0.183 & 0.283 & 0.991 & 0.435 \\
\hline At 6 months & $34.54 \pm 8.01$ & $35.95 \pm 8.96$ & $33.34 \pm 8.69$ & 0.255 & 0.771 & 0.890 & 0.298 \\
\hline Change & $2.43 \pm 1.77$ & $3.95 \pm 1.20$ & $4.18 \pm 1.48$ & $<0.001$ & $<0.001$ & $<0.001$ & $<0.001$ \\
\hline At discharge & $45.46 \pm 9.22$ & $46.22 \pm 10.41$ & $42.86 \pm 10.18$ & 0.199 & 0.428 & 1.000 & 0.425 \\
\hline Change & $1.30 \pm 1.18$ & $1.95 \pm 1.28$ & $1.82 \pm 1.53$ & 0.043 & 0.021 & 0.240 & 0.943 \\
\hline
\end{tabular}

LVES: Left ventricular end systolic diameter 
Table 4(b)

\begin{tabular}{|c|c|c|c|c|c|c|c|}
\hline \multirow[t]{3}{*}{ LV ED(mm) } & \multicolumn{3}{|c|}{ Chordal Preservation } & \multirow[t]{3}{*}{$p$ value } & \multirow{3}{*}{$\begin{array}{c}\text { No } \\
\text { V/S } \\
\text { Posterior }\end{array}$} & \multirow{3}{*}{$\begin{array}{c}\text { No } \\
\text { V/S } \\
\text { Total }\end{array}$} & \multirow{3}{*}{$\begin{array}{c}\text { Posterior } \\
\text { V/S } \\
\text { Total }\end{array}$} \\
\hline & $\begin{array}{c}\text { No } \\
\text { (Group-A) }\end{array}$ & $\begin{array}{l}\text { Posterior } \\
\text { (Group-B) }\end{array}$ & $\begin{array}{c}\text { Total } \\
\text { (Group-C) }\end{array}$ & & & & \\
\hline & Mean \pm SD & Mean \pm SD & Mean \pm SD & & & & \\
\hline Preop & $48.89 \pm 9.66$ & $52.84 \pm 10.92$ & $50.3 \pm 10.88$ & 0.132 & 0.140 & 0.903 & 0.507 \\
\hline At 6 months & $45.46 \pm 9.22$ & $46.22 \pm 10.41$ & $42.86 \pm 10.18$ & 0.199 & 0.970 & 0.548 & 0.223 \\
\hline At discharge & $48 \pm 9.41$ & $49.86 \pm 10.55$ & $47 \pm 10.62$ & 0.294 & 0.705 & 0.959 & 0.381 \\
\hline Change at 6 months & $3.43 \pm 1.79$ & $6.62 \pm 1.63$ & $7.43 \pm 1.77$ & $<0.001$ & $<0.001$ & $<0.001$ & 0.038 \\
\hline Change at discharge & $0.89 \pm 1.07$ & $2.98 \pm 1.15$ & $3.3 \pm 0.98$ & $<0.001$ & $<0.001$ & $<0.001$ & 0.273 \\
\hline
\end{tabular}

LVED: Left ventricular end diastolic diameter

There is a non significant dilation of Left ventricular end systolic dimension in all groups at the time of discharge, however at 6 months follow up there is a reduction systolic dimension noted in all groups and the effect is maximum in Group $C$ when compared with Group A and B ( $p<0.001)$. All groups showed significant reduction in end diastolic dimensions at the time of discharge and at 6 months follow up. Though the pre operative end diastolic dimensions are more in Group-B but the dimensional reduction is noted most and statistically significant in Group-C. The reduction in diastolic diameter in Group $\mathrm{C}$ is not statistically significant when compared with Group B at the time of discharge $(\mathrm{p}=0.0273)$ and at 6 month follow $\mathrm{up}(\mathrm{p}=0.038)$.

Effect on Left ventricular ejection fraction (LVEF): Table 5

\section{Table 5}

\begin{tabular}{|c|c|c|c|c|c|c|c|}
\hline \multirow[t]{3}{*}{ LVEF(\%) } & \multicolumn{3}{|c|}{ Chordal Preservation } & \multirow[t]{3}{*}{ p value } & \multirow{3}{*}{$\begin{array}{c}\text { No } \\
\text { V/S } \\
\text { Posterior }\end{array}$} & \multirow{3}{*}{$\begin{array}{c}\text { No } \\
\text { V/S } \\
\text { Total }\end{array}$} & \multirow{3}{*}{$\begin{array}{c}\text { Posterior } \\
\text { V/S } \\
\text { Total }\end{array}$} \\
\hline & $\begin{array}{c}\text { No } \\
\text { (Group-A) }\end{array}$ & $\begin{array}{c}\text { Posterior } \\
\text { (Group-B) }\end{array}$ & $\begin{array}{c}\text { Total } \\
\text { (Group-C) }\end{array}$ & & & & \\
\hline & Mean \pm SD & Mean \pm SD & Mean \pm SD & & & & \\
\hline Preop & $57.35 \pm 4.06$ & $58.00 \pm 3.30$ & $57.91 \pm 4.02$ & 0.659 & 0.778 & 0.901 & 0.999 \\
\hline At 6 months & $54.49 \pm 4.83$ & $55.47 \pm 4.33$ & $55.3 \pm 4.39$ & 0.525 & 0.639 & 0.819 & 0.996 \\
\hline At discharge & $52.57 \pm 7.05$ & $52.23 \pm 5.75$ & $51.32 \pm 5.08$ & 0.595 & 0.992 & 0.752 & 0.732 \\
\hline Change at 6 months & $2.86 \pm 3.99$ & $2.53 \pm 3.69$ & $2.56 \pm 3.91$ & 0.899 & 0.961 & 0.980 & 1.000 \\
\hline Change at discharge & $4.78 \pm 5.40$ & $5.77 \pm 5.24$ & $6.59 \pm 4.63$ & 0.289 & 0.727 & 0.304 & 0.74 \\
\hline
\end{tabular}

LVEF: Left ventricular ejection fraction

There is a non significant reduction in LVEF seen in all the groups at the time discharge and all the groups showed improvement in ejection fraction at 6months follow up which is statistically non significant.

Effect on Left atrial (LA) Size: Table 6

Table 6

\begin{tabular}{|c|c|c|c|c|c|c|c|}
\hline \multirow[t]{3}{*}{ LAES(mm) } & \multicolumn{3}{|c|}{ Chordal Preservation } & \multirow[t]{3}{*}{ p value } & \multirow{3}{*}{$\begin{array}{c}\text { No } \\
\text { V/S } \\
\text { Posterior } \\
\end{array}$} & \multirow{3}{*}{$\begin{array}{c}\text { No } \\
\text { V/S } \\
\text { Total } \\
\end{array}$} & \multirow{3}{*}{$\begin{array}{c}\text { Posterior } \\
\text { V/S } \\
\text { Total }\end{array}$} \\
\hline & No & Posterior & Total & & & & \\
\hline & Mean \pm SD & Mean \pm SD & Mean \pm SD & & & & \\
\hline preoplaes & $51.73 \pm 16.82$ & $45.93 \pm 14.95$ & $53.15 \pm 19.09$ & 0.036 & 0.208 & 0.978 & 0.092 \\
\hline post op laes & $49.24 \pm 13.88$ & $43.08 \pm 12.54$ & $46.98 \pm 12.7$ & 0.037 & 0.068 & 0.833 & 0.270 \\
\hline Change & $2.48 \pm 6.70$ & $2.6 \pm 8.12$ & $3.18 \pm 18.10$ & 0.199 & 1.000 & 0.515 & 0.521 \\
\hline
\end{tabular}

LAES: Left atrial end systolic diameter

There is a non significant reduction in LA size noted in all the groups. 
Effect on Atrial fibrillation: Table 7

Table 7

\begin{tabular}{|c|c|c|c|c|c|c|c|c|c|}
\hline \multirow[t]{2}{*}{ RHYTHM } & \multicolumn{2}{|c|}{ No } & \multirow{2}{*}{$\begin{array}{c}\mathbf{p} \\
\text { value }\end{array}$} & \multicolumn{2}{|c|}{ Post } & \multirow[t]{2}{*}{ p value } & \multicolumn{2}{|c|}{ Total } & \multirow{2}{*}{$\begin{array}{c}\mathbf{p} \\
\text { value }\end{array}$} \\
\hline & Pre & Post & & Pre & Post & & Pre & Post & \\
\hline $\begin{array}{l}\text { AF } \\
\text { (Rate-80-120bpm) }\end{array}$ & $\begin{array}{c}7 \\
(18.9 \%)\end{array}$ & $4(10.8 \%)$ & 0.515 & $\begin{array}{c}15 \\
(17.2 \%)\end{array}$ & $\begin{array}{c}11 \\
(12.6 \%)\end{array}$ & 0.524 & $8(18.2 \%)$ & $3(6.8 \%)$ & 0.196 \\
\hline $\begin{array}{l}\mathrm{AF} / \mathrm{CVR} \\
(\mathrm{Rate}<80 \mathrm{bpm})\end{array}$ & $3(8.1 \%)$ & $5(13.5 \%)$ & 0.711 & $\begin{array}{c}10 \\
(11.5 \%)\end{array}$ & $\begin{array}{c}12 \\
(13.8 \%)\end{array}$ & 0.691 & $5(11.4 \%)$ & $\begin{array}{c}5 \\
(11.4 \%) \\
\end{array}$ & 1.000 \\
\hline $\begin{array}{l}\text { AF/FVR } \\
\text { (Rate:120-160bpm) }\end{array}$ & $2(5.4 \%)$ & - & 0.493 & $\begin{array}{c}11 \\
(12.6 \%)\end{array}$ & 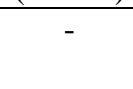 & $<0.001$ & $\begin{array}{c}13 \\
(29.5 \%) \\
\end{array}$ & - & $<0.001$ \\
\hline NSR & $\begin{array}{c}25 \\
(67.6 \%)\end{array}$ & $28(75.7 \%)$ & 0.607 & $\begin{array}{c}51 \\
(58.6 \%)\end{array}$ & $\begin{array}{c}64 \\
(73.6 \%)\end{array}$ & 0.037 & $\begin{array}{c}18 \\
(40.9 \%)\end{array}$ & $\begin{array}{c}36 \\
(81.8 \%)\end{array}$ & $<0.001$ \\
\hline Total & $\begin{array}{c}37 \\
(100 \%)\end{array}$ & $37(100 \%)$ & & $\begin{array}{c}87 \\
(100 \%)\end{array}$ & $\begin{array}{c}87 \\
(100 \%)\end{array}$ & & $44(100 \%)$ & $\begin{array}{c}44 \\
(100 \%)\end{array}$ & \\
\hline
\end{tabular}

AF:atrial fibrillation (ventricular rate 81-120 beats per minute),CVR:controlled ventricular rate( $<80$ beats per minute), FVR: fastventriculae rate(120-160 beats per minute), NSR: normal sinus rhythm

Conversion to Normal sinus rhythm in immediate post operative period is statistically significant in Group C $(\mathrm{p}<0.001)$ where as not significant in Group B ( $\mathrm{p}=0.0273)$ and $\mathrm{A}(\mathrm{p}=0.038)$.

There is a significant increase in cross clamp time and cardio pulmonary bypass time noted in Group-C $(\mathrm{p}<0.001)$. Group- $\mathrm{C}$ also received a bigger size prosthesis though statistically not significant.

Except for one patient in group-B had a post operative stroke there is no other major adverse cardiaovascular event noted in all the groups. No prosthetic valve dysfunction and operative mortality observed in all the groups.

Effect on NYHA Function: Table 8 (a) \& 8 (b)

Table 8 (a)

\begin{tabular}{|l|c|c|c|c|}
\hline \multirow{2}{*}{$\begin{array}{l}\text { NYHA (Pre- } \\
\text { operative) }\end{array}$} & \multicolumn{3}{|c|}{ Chordal Preservation } & \multirow{2}{*}{ p } \\
\cline { 2 - 4 } & No & Post & Total & \multirow{2}{*}{0.661} \\
\cline { 2 - 4 } & Frequency (\%) & Frequency (\%) & Frequency (\%) & \\
\hline II & $36(97.3 \%)$ & $79(90.8 \%)$ & $39(88.6 \%)$ & \\
\hline III & $1(2.7 \%)$ & $7(8.0 \%)$ & $4(9.1 \%)$ & \\
\hline IIII & $0(0.0 \%)$ & $1(1.1 \%)$ & $1(2.3 \%)$ & \\
\hline Total & $37(100 \%)$ & $87(100 \%)$ & $44(100 \%)$ & \\
\hline
\end{tabular}

Table 8 (b)

\begin{tabular}{|l|c|c|c|c|c|c|}
\hline \multicolumn{2}{|l|}{ NYHA (Post-operative) } & I & II & III & IV & Total \\
\hline \multirow{2}{*}{ No } & Pre & & $36(97.3 \%)$ & $1(2.7 \%)$ & & $37(100 \%)$ \\
\cline { 2 - 7 } & Post & $30(81.1 \%)$ & $7(18.9 \%)$ & & & $37(100 \%)$ \\
\hline p value & & $<0.001$ & $<0.001$ & 1.000 & & \\
\hline \multirow{2}{*}{ Post } & Pre & & $79(90.8 \%)$ & $7(8.0 \%)$ & $1(1.1 \%)$ & $87(100 \%)$ \\
\cline { 2 - 7 } & Post & $59(67.8 \%)$ & $28(32.2 \%)$ & & & $87(100 \%)$ \\
\hline p value & & $<0.001$ & $<0.001$ & $<0.001$ & 1.000 & \\
\hline \multirow{2}{*}{ Total } & Pre & & $39(88.6 \%)$ & $4(9.1 \%)$ & $1(2.3 \%)$ & $44(100 \%)$ \\
\cline { 2 - 7 } & Post & $34(77.3 \%)$ & $10(22.7 \%)$ & & & $44(100 \%)$ \\
\hline p value & & $<0.001$ & $<0.001$ & 0.116 & 1.000 & \\
\hline
\end{tabular}

There has been overall decrease in symptoms in all the three groups with maximum improvement in symptoms Total Chordal Preservation group as per NYHA grading.

\section{Discussion}

Wiggers and $\mathrm{Katz}^{10}$ first proposed the concept of annulo papillary continuity and later on by Rushmer et $a l^{11}$. As per this concept, there is a dynamic interaction between the mitral annulus and left ventricular wall which is responsible for 
the LV function and geometry. The first MVR was reported in 1961 using (Starr-Edwards prosthetic valve) and it involved complete excision of mitral leaflets, chordae tendineae and tips of the papillary muscles. ${ }^{12}$ Initially, there was an increased incidence of low cardiac output syndrome and associated mortality.Despite satisfactorily functioning prosthetic valves, approximately $50 \%$ of patients were dying from heart failure within 5 years. Post mortem examination revealed a globular remodeling of the ventricular cavity. In 1964, Lillehei tried to reduce postoperative low cardiac output syndrome by adapting to the concept of chordal preservation ${ }^{13}$ and subsequently reported a reduction in operative mortality from $37 \%$ to $14 \% .^{14,15}$

Rastelli experimented on animal models and concluded that after mitral valve replacement with Starr-Edwards prosthesis, the cardiac performance was unaffected irrespective of whether the chordae were preserved or resected. ${ }^{16}$ In a randomized trial, David in 1994, showed that chordal preservation resulted in better LV function than those with no preservation, even after 7 years ${ }^{17}$,

Hansen et al demonstrated LV function was more affected when the chordae to the AML were excised as compared to those of the $\mathrm{PML}^{18}$ and chordal preservation is superior to conventional MVR in terms of exercise capacity, LV systolic dimensions and ejection fraction was shown by Rozich $^{19}$ and colleagues and Hannin ${ }^{3}$ and colleagues. Hansen observed best LV function with preservation. of the entire subvalvular apparatus, reasonable with preservation of either the AML or PML and poorest with transection of all chordate. Our study revealed improved functional outcome, improvement of LV function and better remodeling of LV diameters with total chordal preservation group corroborating with the other studies ${ }^{18,19,21,22}$. The functional outcome in our patients in addition to the above mentioned factors also attributed to the reduction of size of left atrium and restoration of normal sinus rhythm in immediate post operative period.
Microsimulation study done by Christopher Rao et al., revealed longer survivality and better quality of life with complete preservation of sub valvular apparatus. ${ }^{20}$

Chowdhury et al, concluded that chordal preservation either posterior or total results in significant improvement in LV function immediately or late postoperatively. The total chordal preservation group did demonstrate greater fractional change of LV end systolic volume as compared to posterior chordal preservation and nonchordalgroup. ${ }^{21,22}$

\section{Conclusion}

The technical complexity in total chordal preservation do not undermine the beneficial effects of better left ventricular remodelling, preservation of heart function and functional out come in patients undergoing mitral valve replacement.

\section{Study Limitations}

This is a retrospective study, hence we did not emphasise on the stenotic or regurgitant lesions separately as these did not influence in picking up total, less or no chordal preservation strategies, which otherwise could have pronounced a significance in left ventricular function. At the time of surgery operating surgeon was the deciding factor for choice of procedure of chordal resection, posterior mitral valve preservation or total chordal preservation .Patient factors which influenced the strategy are severe subvalvular calcification and size of mitral valve annulus .

Follow up of patients was restricted to six months because of remote access, poor transportation and low socioeconomic status. Multiple echocardiographers and echo machines were used during study. However, all the echocardiographers were certified cardiologists from the same department.

\section{References}

1. Lillehei C.W. New ideas and their acceptance as it has related to reservation 
of chordae tendinae and certain other discoveries. JHeart Valve Dis 1995;4 (suppl 2):S106-14.

2. Le Tourneau T., Grandmougin D., Foucher C., McFadden E.P, de Groote P., Prat A., et al. Anterior chordal transection impairs not only regional left ventricular function but also regional right ventricular function in mitral regurgitation. Circulation 2001;104(suppl 1):141-6.

3. Hannein H.A., Swain J.A., McIntosh C.L., Bonow R.O., Stone C.D.,Clark R.E. Comparative assessment of chordal preservation versus chordal resection during mitral valve replacement. J Thorac Cardiovasc Surg 1990;99:828-37.

4. Kayacioglu I., Ates M., Sensoz Y., Gorgulu S., Idiz M., Kanca A. Comparative assessment of chordal preservation versus chordal resection in mitral valve replacement for mitral stenosis (long term follow-up: 8 years). Tohoku J Exp Med 2003;200:119-28.

5. Thomson L.E., Chen X., Greaves S.C. Entrapment of mitral chordal apparatus causing early postoperative dysfunction of aSt. Judemitral prosthesis. J Am Soc Echocardiogr 2002;15:843- 4.

6. De Canniere D., Jansens J., Unger P., Le Clerc J. Left ventricular outflow obstruction after mitral valve replacement. Ann ThoracSurg 1997;64:1805-6

7. Miki S., Kusuhara K., Ueda Y., Komeda M., Ohkita Y.,Tahata T. Mitral valve replacement with preservation of chordae tendinae and papillary muscles. Ann Thorac Surg 1988;45:28-34.

8. Bonow R.O., Carabello B.A., Kanu C., de Leon A.C. Jr, Faxon D.P., Freed M.D., et al. ACC/AHA 2006 guidelines for the management of patients with valvular heart disease: a report ofthe American College of Cardiology/American Heart Association Task Force on Practice
Guidelines. Circulation 2006;114:e84231.

9. Douglas P.S., Khandheria B., Stainback R.F, Weissman N..J..,Brindis R.G., Patel M.R., ACCF/ASE/ACEP/ASNC/SCAI/ SCCT/SCMR 2007 appropriateness criteria for transthoracic and transesophageal echocardiography: a report of the American College of Cardiology Foundation Quality Strategic Directions Committee Appropriateness Criteria Working Group, American Society of Echocardiography, American College of Emergency Physicians, American Society ofNuclear Cardiology, Society for Cardiovascular Angiography and Interventions, Society of Cardiovascular Computed Tomography, and the Society for Cardiovascular Magnetic Resonance endorsed by the American College of Chest Physicians and the Society of Critical Care Medicine. J Am CollCardiol 2007;50:187-204.

10. Wiggers C.S., Katz L.M. Contour of the ventricular volume curves under different conditions. Am J Physiol 1922;58:439-75.

11. Rushmer R.F., Finlayson B.L., Nash A.A. Movements of the mitral valve. Circ Res 1956;4:337-42.

12. Starr A., Edwards M.L. Mitral valve replacement: clinical experience with a ball prosthesis. Ann Surg 1961;154:726.

13. Lillehei C.W., Levy M.J., Bonnabeau R.C. Mitral valve replacement with preservation of papillary muscles and chordae tendinae. J Thorac Cardiovasc Surg 1964;47:532-43.

14. Lillehei C.W. Value of preserving chordal integrity. Both experimental and clinical data. J Thorac Cardiovasc Surg 1963; 46:494-5.

15. Lillehei C.W., Levy M.J., Bonnabeau R.C. Complete mitral valve replacement preserving papillary muscle-chordae tendineaeannulus continuity. Circulation 1963;28:757. 
16. Rastelli G.C., Tsakiris A.G., Banchero N., Wood E.H., Kirklin J.W. Cardiac performance after replacement of the dog mitral valve with Starr-Edwards prosthesis with and without preservation of the chordae tendinae. Surg Forum 1966;17:178-79

17. Komeda M., David T.E., Rao V., Sun Z., Weisel R.D., Burns R.J. Late hemodynamic effects of the preserved papillary muscles during mitral valve replacement. Circulation 1994;90:II190-4.

18. Hansen D.E., Cahill P.D., Derby G.C., Miller D.C. Relative contributions of the anterior and posterior mitral chordae tendineae to canine global left ventricular function. J Thorac Cardiovasc Surg 1987;93:45-55.

19. Rozich J.D., Carabello B.A., Usher B.W., Kratz J.M., Bell A.E., Zile M.R. Mitral valve replacement with and without chordalpreservation in patients with chronic regurgitation: mechanism for differences in postoperative ejection performance. Circulation 1992;86:171826.

20. Rao C., Hart J., Chow A., Siannia F, et al. Does preservation of the subvalvularapparatus during mitral valve replacement affect long term survival and quality of life? A Microsimulation Study. Journal of Cardiothoracic Surgery 2008, $3: 17$

21. Chowdhury U.K., Kumar A.S., Airan B., Mittal D., SubramaniamG., Prakash R., et al. Mitral Valve Replacement with and without Chordal Preservationin a Rheumatic Population: Serial echocardiographic Assessment of Left Ventricular Size and Function. Ann Thorac Surg 2005; 79: 1926-33.
22. García-Fuster R., Estevez V., Gil O., Cánovas S., Martínez-Leon J.Mitral valve replacement in rheumatic patients: effects of chordalpreservation. Ann Thorac Surg 2008;86:472-81. 